\title{
Quantitative Detection of Pathogen DNA of Verticillium Wilt on Smoke Tree Cotinus coggygria
}

Yonglin Wang, Yan Wang, and Chengming Tian, The Key Laboratory for Silviculture and Conservation of Ministry of Education, College of Forestry, Beijing Forestry University, Beijing 100083, China

\begin{abstract}
Wang, Y. L., Wang, Y., and Tian, C. 2013. Quantitative detection of pathogen DNA of Verticillium wilt on smoke tree Cotinus coggygria. Plant Dis. 97:1645-1651.

Verticillium dahliae is a ubiquitous soilborne fungus and the causal agent of smoke tree vascular wilt, which presents a major threat to the famous "red-leaf" scenery of the Fragrant Hills Park in Beijing, China. In this study, we detected the presence of the fungus based on the amount of fungal DNA in planta and in the soil by using quantitative nested real-time polymerase chain reaction (QNRT-PCR). The QNRTPCR assay results were highly specific for $V$. dahliae and could detect disease wilt dynamics over time in different plant tissues. Tests with QNRT-PCR in infested soils showed the detection of soil inoculum

densities as low as 1 microsclerotium/g of soil. The QNRT-PCR data showed strong correlation between the quantity of pathogen DNA and the Verticillium wilt disease severity rating, suggesting that quantification of $V$. dahliae soil inoculum could be conducted to assess Verticillium wilt risk before planting. These data indicate that QNRT-PCR is a sensitive and reliable method to monitor the soilborne pathogen $V$. dahliae in planta and in soil. The results of this study can be useful in the development of new disease control measures for Verticillium wilt and assessment of the risk of $V$. dahliae infection of smoke tree before planting.
\end{abstract}

Smoke trees (Cotinus coggygria Scop.) are an important colored-leaf tree species that constitute the majority of the famous "red-leaf" scenery of Fragrant Hills Park, which is a large forest park covering 160 ha in Beijing, China. Smoke trees are naturally established in Fragrant Hills Park and their leaves become red after late autumn frosts to produce the most beautiful natural attraction of red-leaf scenery in Beijing. In recent years, smoke tree vascular wilt has emerged and has a significant economic and ecological impact on the red-leaf landscape. The disease has appeared sporadically in Fragrant Hills Park since the 1990s but, since 2003, the wilt spread widely in the Fragrant Hills region as well as in some parts of Shandong province. Currently, the wilt is the most devastating disease affecting smoke trees. It results in stunted growth, early senescence, and severe mortality. Verticillium dahliae Kleb. is responsible for the smoke tree vascular wilt (31). V. dahliae, a ubiquitous soilborne disease throughout the world, causes wilt in a wide variety of plants, including woody trees, economic crops (sunflower and cotton), vegetables, fruit, and flowers $(8,23)$. This pathogen can produce melanized, multicellular survival structures known as microsclerotia that represent a significant stage in its life cycle because they can persist for years in the soil $(16,24)$. The control of Verticillium wilt is heavily reliant on soil fumigation (23). The soil inoculum density is the determinant factor for the usage of soil fumigation. Thus, it is necessary to monitor the persistence and quantity of this fungus in the soil and in planta.

Due to an advantage in sensitivity, specificity, flexibility, and speed, polymerase chain reaction (PCR) is an efficient method for amplifying specific DNA sequences and is frequently used to detect plant pathogens. Ribosomal DNA (rDNA) internally transcribed spacer (ITS) regions surrounding the 5.8S rDNA are widely targeted for specifically detecting many fungi, including plant pathogens $(1,12,14,27,29)$. In order to detect Verticillium spp., several PCR primers have been targeted for this region or other species-specific DNA sequences $(2,3,5,6,11,18,21)$. Conven-

Corresponding author: C. Tian, E-mail: chengmt @bjfu.edu.cn

Accepted for publication 30 May 2013.

http://dx.doi.org/10.1094/PDIS-04-13-0406-RE

(C) 2013 The American Phytopathological Society tional PCR assays based on single or nested primers have been described for the detection of $V$. dahliae in qualitative or semiquantitative ways $(13,22,25)$. In addition, techniques based on real-time (RT)-PCR can provide a more accurate quantification of the pathogen with a higher level of sensitivity. There are various reports of the detection and quantification of $V$. dahliae in soil and in planta using RT-PCR assays $(2,3,5-7,9,17,19)$. For example, Lievens et al. (19) reported a SYBR Green-based assay that targeted an rDNA ITS for the quantification of Verticillium spp. infecting tomato. More recently, Bilodeau et al. (5) developed a quantification assay for $V$. dahliae in soil samples, with an internal control probe serving as an internal reference for each amplification. Furthermore, sensitivity of quantitative (q)PCR can be improved by applying a nested approach. Banno et al. (3) reported the development of quantitative nested (QN)RT-PCR to estimate the risk of Verticillium wilt in cabbage fields. Though there are many reports of progress in the development of PCR methods for the detection and quantification of $V$. dahliae in agronomy, there are few published studies addressing the detection and quantification of $V$. dahliae in woody trees or forest soil. Schena et al. (28) reported a RT-PCR technique based on Scorpion primers designed against species-specific sequences of rDNA intergenic spacers, which were used as a target for detecting $V$. dahliae in olive trees. Verticillium wilt is so highly variable and difficult to diagnose in smoke trees that the establishment of a rapid and accurate method is of great importance for analyzing pathogen dynamics throughout the disease cycle and for quantifying pathogen populations in the soil and in planta. This method will be useful for the detection and quantification of $V$. dahliae in trees with wilt-like symptoms as well as in the soil.

The aim of this study was to develop effective disease control measures and risk assessment methods for the detection of $V$. dahliae in field soil and in planta. We chose an experimental strategy that correlated $V$. dahliae dynamics over time in different plant tissues with the development of symptoms in infected plants and the presence of the pathogen in soil samples. Fungal DNA was detected by using QNRT-PCR assays and the Verticillium fungal inocula were quantified by QNRT-PCR and plating assays of samples from smoke trees in natural field plots.

\section{Materials and Methods}

Experimental site. Fragrant Hills is located in the northwest of Beijing and covers an area of 160 ha. Smoke trees are the main tree 
there. In Fragrant Hills Park, the smoke tree field covers more than 80 ha. We randomly selected four plots, each with 50 trees and covering about $100 \mathrm{~m}^{2}$, to investigate wilt progress and collect plant tissues for isolating smoke tree wilt fungus and quantifying the pathogen DNA.

Disease surveys. Smoke trees in Fragrant Hills were surveyed for the incidence and severity of Verticillium wilt during 2008 to 2011. In total, four plots in Fragrant Hills Park were surveyed. We first investigated each smoke tree in the plots every 2 months from spring to autumn and calculated Verticillium wilt incidence and disease rating during the latter part of the growing season, when the foliar symptoms were prominent. Smoke trees were examined visually for symptoms of Verticillium wilt. The number of symptomatic plants of 50 consecutive plants in each plot was recorded and the percentage of the disease incidence was calculated for each plot. For each plant, the Verticillium wilt disease rating was assessed on a scale of 0 to 4 , where $0=$ no wilting, $1=$ yellowing or wilting of $<5$ leaves, $2=$ yellowing or wilting of 5 to 10 leaves, $3=$ yellowing or wilting of the leaves on two-thirds of the stems, and 4 $=$ more than $85 \%$ of the leaves wilted or dropped or the whole plant dead.

Fungal strains. The fungal isolates used in this study (Table 1) included isolates that were representative of the major Verticillium spp. (i.e., V. dahliae, V. albo-atrum, V. nigrescens, and V. tricor-

Table 1. Fungal isolates to evaluate the specificity of primer pairs in this study

\begin{tabular}{|c|c|c|c|c|}
\hline \multirow[b]{2}{*}{ Species $^{w}$} & \multirow[b]{2}{*}{$N^{\mathrm{x}}$} & \multirow[b]{2}{*}{ Host or source } & \multicolumn{2}{|c|}{ PCR product ${ }^{v}$} \\
\hline & & & $\begin{array}{l}\text { ITS 1/ } \\
\text { ITS 4y }\end{array}$ & $\begin{array}{l}\text { VdF2/ } \\
\text { VdR2 }^{z}\end{array}$ \\
\hline Verticillium dahliae & 50 & Smoke tree & + & + \\
\hline V. dahliae & 4 & Cotton & + & + \\
\hline V. dahliae & 20 & Smoke tree field soil & + & + \\
\hline V. albo-atrum & 4 & Cotton & + & - \\
\hline V. nigrescens & 4 & Potato & + & - \\
\hline V. tricorpus & 1 & Potato & + & - \\
\hline Trichoderma harzianum & 5 & Smoke tree field soil & + & - \\
\hline Penicillium spp. & 6 & Smoke tree field soil & + & - \\
\hline Cylindrosporium sp. & 5 & Smoke tree field soil & + & - \\
\hline Fusarium spp. & 8 & Smoke tree field soil & + & - \\
\hline Oidiodendron sp. & 6 & Smoke tree field soil & + & - \\
\hline Gliomastix sp. & 4 & Smoke tree field soil & + & - \\
\hline Cryphonectria parasitica & 1 & Chestnut & + & - \\
\hline Xylaria hypoxylon & 2 & Orchids root & + & - \\
\hline Rhizoctonia solani & 1 & Unknown & + & - \\
\hline Pythium ultimum & 2 & Soil & + & - \\
\hline \multicolumn{5}{|c|}{$\begin{array}{l}{ }^{\mathrm{v}} \text { Polymerase chain reaction }(\mathrm{PCR}) \text { product: }+=\text { expected } \mathrm{PCR} \text { product } \\
\text { present and }-=\text { no PCR product band. }\end{array}$} \\
\hline $\begin{array}{l}{ }^{\mathrm{w}} \text { All } V \text {. dahliae isolates ar } \\
\text { maintained in the colle } \\
\text { Center. All other fungal } \\
{ }^{\mathrm{x}} \text { Number of isolates. } \\
\text { y Universal primers intern } \\
\text { to detect fungal strains. } \\
{ }^{\mathrm{z}} \mathrm{VdF} 2 / \mathrm{VdR} 2 \text { was the spe }\end{array}$ & $\begin{array}{l}\text { isoil } \\
\text { tion } \\
\text { olate }\end{array}$ & $\begin{array}{l}\text { ungal isolates from sm } \\
\text { f the China Forestry } \\
\text { were collected in the s } \\
\text { cribed spacer (ITS) } 1 \text { a }\end{array}$ & $\begin{array}{l}\text { oke tree } \mathrm{f} \\
\text { Culture } \\
\text { tudy. } \\
\text { nd ITS } 4\end{array}$ & $\begin{array}{l}\text { elds were } \\
\text { Collection } \\
\text { vere used }\end{array}$ \\
\hline
\end{tabular}

pus). To evaluate the potential of common soil fungi to interfere with the $V$. dahliae detection assay, we used other fungal strains which were maintained in the China Forestry Culture Collection Center, Beijing or were isolated from the soil of smoke tree fields in this study. For soil fungal isolates, $1 \mathrm{~g}$ of field soil taken from smoke tree fields was diluted in $9 \mathrm{ml}$ of sterile water. Six 1:10 serial dilutions were done. Each dilution $(250 \mu \mathrm{l})$ was plated on five plates of potato dextrose agar (PDA)-rose-bengal medium (PDA, rose Bengal at $40 \mu \mathrm{g} / \mu \mathrm{l}$, and rifampicin at $25 \mu \mathrm{g} / \mathrm{ml}$ ) and incubated at $25^{\circ} \mathrm{C}$ for 5 days. Morphologically different colonies were transferred to new plates and purified in PDA medium for several days. Pure cultures from single-spore isolates were established for DNA extraction.

Isolation of the pathogen from smoke tree. To isolate the pathogen from diseased smoke trees, sections of stem or petiole were quickly washed by $75 \%$ ethanol, then superficially disinfected with sodium hypochlorite $(0.5 \%$ available chlorine) for 2 min (petiole) or $3 \mathrm{~min}$ (stems), rinsed three times in sterile water, and dried before plating onto PDA. The plates were incubated in the dark at $25^{\circ} \mathrm{C}$ for 1 or 2 weeks. The isolates were identified as $V$. dahliae based on the appearance of typical cultures, conidia morphology and phialides produced in a whorl around each conidiophore. The remaining plant samples were saved for DNA isolation and RT-PCR assays.

DNA extraction. Genomic DNA of fungal isolates in Table 1 was extracted using the cetyltrimethylammonium bromide method modified from Stewart et al. (30). Extracted DNA was dissolved in $40 \mu \mathrm{l}$ of double-distilled (dd) $\mathrm{H}_{2} \mathrm{O}$ and stored at $-20^{\circ} \mathrm{C}$ until further use. The ITS region was amplified using primers ITS 1 and 4 (Table 2) and the amplicons were sequenced at Invitrogen Technologies (Shanghai). Taxonomic identification of the isolates was done by BLAST analysis against GenBank.

To extract DNA from roots, stems, and leaves of smoke trees, tissue was frozen in liquid nitrogen and heavily ground with a mortar and pestle. Then, the total DNA was extracted from diseased plant materials using Plant Genomic DNA Kit (DP305; Tiangen) according to the manufacturer's instructions. For DNA extraction from soil, samples were collected from three randomly selected points in each plot on 10 September 2011. Approximately $100 \mathrm{~g}$ of soil at a depth of $10 \mathrm{~cm}$ was dug from each point using a shovel, then mixed thoroughly in a plastic bag before DNA extraction. Soil genomic DNA was extracted using a Soil DNA Extraction Kit (Tiangen), according to the manufacturer's instructions. The quality of DNA was measured by agarose electrophoresis and the quantity of DNA was determined by NanoDrop Spectrophotometers (ND-1000; Thermo Fisher Scientific).

Primer design and Verticillium spp.-specific PCR. To obtain suitable primers for SYBR Green PCR, a high copy number region of rDNA $18 \mathrm{~S}-5.8 \mathrm{~S}-28 \mathrm{~S}$ was used to design primers. An alignment of sequences from different Verticillium spp. in GenBank was used to design $V$. dahliae species-specific PCR primers (Table 2). The web-based programs Primer3 and BioEdit were used for primer design. Amplicons of $100 \mathrm{bp}$ were putatively amplified by the forward and reverse primers. Primer specificity was tested using

Table 2. Primer sets used for conventional polymerase chain reaction (PCR) and SYBR Green nested real-time PCR

\begin{tabular}{|c|c|c|c|c|}
\hline Primer name & Sequence $\left(5^{\prime}-3^{\prime}\right)$ & Amplicon (bp) & Usage & References \\
\hline ITS $1^{\mathrm{w}}$ & TCCGTAGGTGAACCTGCGG & 690 & Amplification of fungal ITS1-5.8S-ITS2 region & Bellemain et al. (2010) \\
\hline ITS2 & TCCTCCGCTTATTGATATGC & & $\ldots$ & 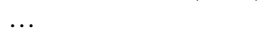 \\
\hline $\mathrm{VdF} 1^{\mathrm{x}}$ & CCGCCGGTCCATCAGTCTCTCTG & 340 & Amplification of 5.8S-ITS region of $V$. dahliae & 3 \\
\hline VdR1 & GGGACTCCGATGCGAGCTGTAAC & & $\ldots$ & \\
\hline $\mathrm{VdF} 2^{\mathrm{y}}$ & CGGATCTCTTGGCTCTAGCA & 100 & Nested PCR amplification for $V$. dahliae & This study \\
\hline VdR2 & CATGTGCGTTCAAAGATTCG & 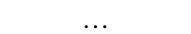 & & \\
\hline Ccrpl1 $^{z}$ & TGCGCCAAGGAAATCTTAAC & 110 & Smoke tree internal control & This study \\
\hline Ccrpl2 & ATCGCATTTCGCTACGTTCT & $\ldots$ & $\ldots$ & $\ldots$ \\
\hline
\end{tabular}

\footnotetext{
${ }^{\mathrm{w}}$ ITS = internal transcribed spacer. See Bellemain et al. 2010. BMC Microbiol. 10, 189.

${ }^{\mathrm{x}}$ Banno et al. (3) designed the primer pair VdF1/R1 according to 5.8S ribosomal DNA-ITS of V. dahliae.

${ }^{y}$ Specific nested primers VdF2/VdR2 were designed based on the amplicon of VdF1/R1 in this study.

${ }^{\mathrm{z}}$ Primer pair of some tree was used as the internal standard.
} 
DNA from the collection described above by both conventional nested PCR and QNRT-PCR. First-round PCR was performed to amplify a wide portion of the ITS region with the primer pair VdF1 and VdR1, and the second PCR product targeted an internal region within the first PCR product with the primers VdF2 and VdR2 (Table 2).

QNRT-PCR. As with conventional nested PCR, QNRT-PCR was performed in two rounds. First-round PCR was identical with that of the conventional nested PCR. The second-round amplification and the product detection were performed with an RT-PCR instrument (ABI 9700; Roche Applied Science) using SYBR Green I with primer VdF2 and VdR2. The RT-PCR amplifications were performed in $20 \mu \mathrm{l}$ reaction mixtures containing $10 \mathrm{ng}$ of total DNA and $200 \mathrm{mM}$ each primer in PCR mix (TaKaRa Bio Inc.). qPCR was performed using ABI7500 (Roche Applied Science). The reaction mixture $(20 \mu \mathrm{l})$ included $20 \mathrm{ng}$ of template DNA, 0.2 $\mu \mathrm{M}$ each primer, $10 \mu \mathrm{l}$ of SYBR Premix ExTaq (TaKaRa Bio Inc.), $0.4 \mu \mathrm{l}$ of $\mathrm{ROX}$, and $7.2 \mu \mathrm{l}$ of $\mathrm{ddH}_{2} \mathrm{O}$. Reactions were performed under the following conditions: $95^{\circ} \mathrm{C}$ for $30 \mathrm{~s} ; 40$ cycles of $95^{\circ} \mathrm{C}$ for $5 \mathrm{~s}$ and $60^{\circ} \mathrm{C}$ for $31 \mathrm{~s}$ to calculate the cycle threshold $(\mathrm{Ct})$ values; followed by $95^{\circ} \mathrm{C}$ for $15 \mathrm{~s}, 60^{\circ} \mathrm{C}$ for $1 \mathrm{~min}$, and then $95^{\circ} \mathrm{C}$ for $15 \mathrm{~s}$ to obtain the melting curves. All the DNA templates in Table 1 were amplified with the designed primers using ABI 7500 according to the instructions. The amplification plot and melting curve analysis were used to evaluate the primer specificity. The 7500 System Sequence Detection program (version 2.0) was used for data analysis. The melting curve analysis was used to dis- tinguish potential primer-dimers and nonspecific amplification products. The fluorescent reporter signal was normalized against the internal reference dye (ROX) signal, and threshold limit setting was performed in the automatic mode, according to the ABI Sequence Detection program version 2.0. All reactions were performed in triplicate and they included parallel reactions of three separate dilution series of pure standard DNA in all PCR amplification runs. The efficiency of qPCR amplifications was evaluated in the experiment. The sensitivity of the RT qPCR protocol was compared with a simple PCR protocol using the specific primers. QNRT-PCR assays were conducted for quantification of fungal biomass in smoke tree plants; total DNA was extracted from naturally infected smoke tree tissues, including roots, stems, branches, and leaves. To normalize the difference in DNA template amounts, the primer pair Ccrpl1/2 (Table 2) was used to amplify the internal gene of smoke tree as standard.

Quantification of $\boldsymbol{V}$. dahliae inoculum in field soil. Microsclerotia of $V$. dahliae were obtained by collecting the dark culture on PDA media at $28^{\circ} \mathrm{C}$ for 2 weeks. The microsclerotia collections were gently ground with a mortar and pestle and sterile water was added. The concentration of microsclerotia in the suspension was determined using a hemocytometer. Sterile soil samples were spiked with different levels of microsclerotia, resulting in 5, 10, 50, 100, and 200 microsclerotia/g of soil.

For soil quantification of the pathogen using molecular assays, DNA was extracted from the soil using the method described above. To determine the relationship between soil plate counts of $V$.

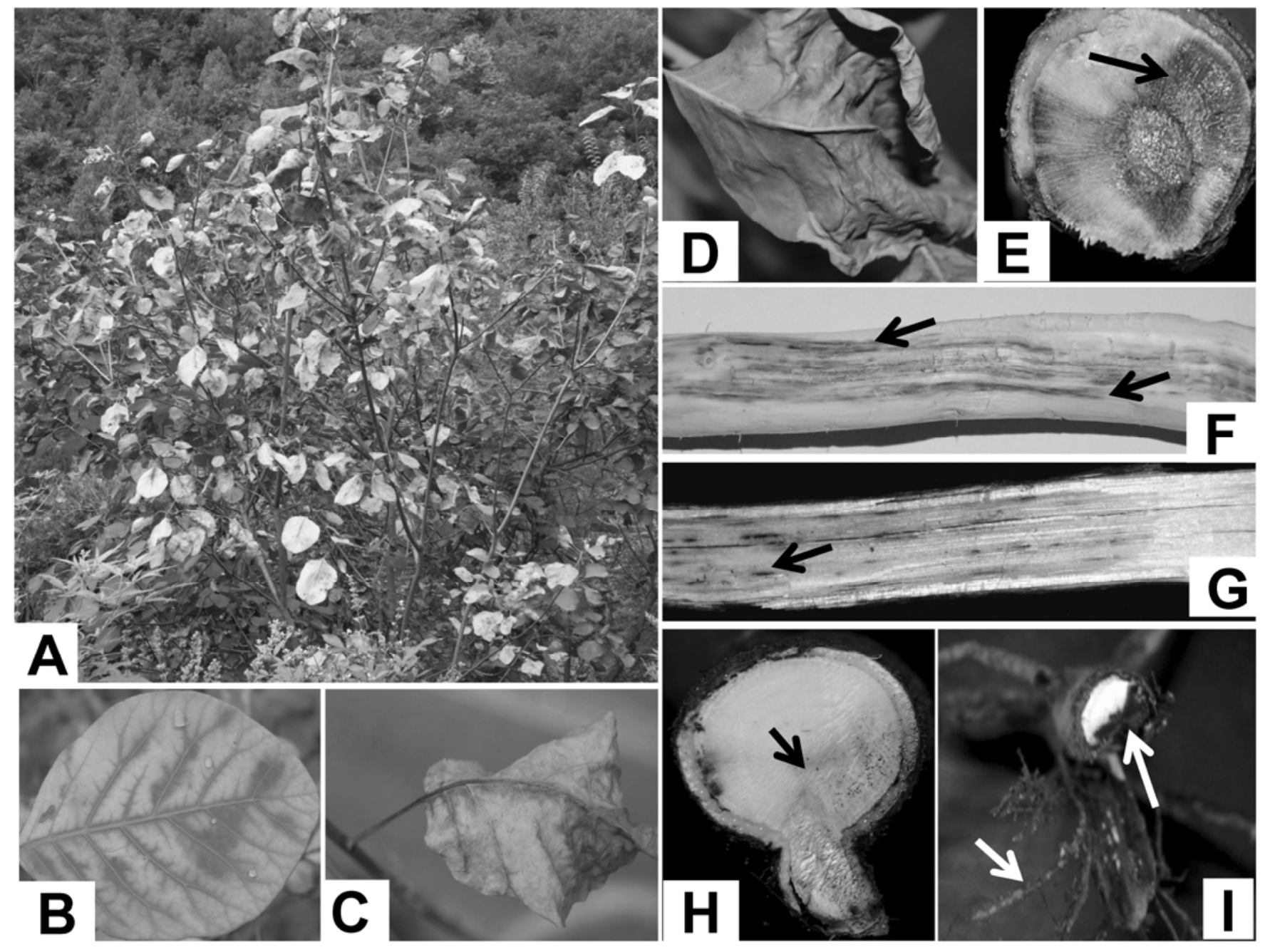

Fig. 1. Verticillium wilt symptoms of infected smoke trees. A, Verticillium wilt of smoke tree. Leaves displaying B, characteristic yellow wilt in the early stage; $\mathbf{C}$, yellow wilt; and $\mathbf{D}$, death in green leaf. Stems displaying $\mathbf{E}$, vessel discoloration (arrows), $\mathbf{F}$, lines of microsclerotia produced by Verticillium dahliae in necrotic stem tissue (arrows), and G, longitudinal section of the stem showing black-brown discoloration (arrow). Root rot of an infected smoke tree: H, rot of main root (arrow), and I, rot of lateral roots and fine root (arrows). 
dahliae inoculum and the results from QNRT-PCR assays, regression analysis was conducted using Microsoft Excel 2007. At the same time, inoculum density of $V$. dahliae in smoke tree field soils was also quantified using selective PDA medium and plate count methods. Smoke tree field soils were air dried at $25^{\circ} \mathrm{C}$, mixed thoroughly, and pulverized with a mortar and pestle. The soil samples were then passed through a 20 -mesh sieve to remove hard particles. Then, for each sample, $10 \mathrm{~g}$ of the sieved soil was diluted with $90 \mathrm{ml}$ of sterile water in a 150-ml Erlenmeyer flask and incubated in the dark at $100 \mathrm{rpm}$ overnight. Soil solution $(200 \mu \mathrm{l})$ was plated on 10 plates of PDA medium containing rose Bengal at 40 $\mu \mathrm{g} / \mu \mathrm{l}$, rifampicin at $10 \mu \mathrm{g} / \mathrm{ml}$, and of ampicillin at $250 \mu \mathrm{g} / \mathrm{ml}$. After 3 weeks of incubation, the plates were examined and colonies of $V$. dahliae counted.

\section{Results}

Symptoms and disease severity of smoke tree wilt. Symptoms of smoke tree Verticillium wilt begin to appear in the late spring. Symptoms include foliar chlorosis and necrosis, stunting, vascular discoloration, and die-back of individual branches and death of the entire tree (Fig. 1A). Leaves first undergo chlorosis (Fig. 1B) and then wilting (Fig. 1C). Some leaves even become necrotic before other symptoms become apparent (Fig. 1D). Vascular discoloration is a distinctive and helpful diagnostic symptom. Infected stems and branches, even the main trunk of the tree, often display vessel discoloration (Fig. 1E, arrows), with lines of microsclerotia in necrotic stem tissue (Fig. 1F, arrows). Longitudinal sections of the stem show black-brown discoloration (Fig. 1G, arrow). Roots of infected plants are often partially or completely deteriorated. Root rot appears on the main root (Fig. 1H, arrow), the lateral roots, and the fine roots of infected smoke trees (Fig. 1I, arrows).

The wilt symptoms usually become prevalent in midsummer and increase until the end of October. Verticillium wilt was confirmed by the examination of the foliar or vascular symptoms and $V$. dahliae isolation from sampled plants. In Fragrant Hill, surveys in the period 2008 to 2011 showed that Verticillium wilt of smoke tree was widespread, with a mean incidence of 72.5 to $90.5 \%$ (Table 3 ). In our surveys conducted over four sequential years, the incidence and disease severity of smoke tree wilt increased. Furthermore, many smoke trees died across the years (Table 3). During 2011, mean incidence and disease severity were significantly higher than in the previous 3 years, and 15 trees died in the surveyed plots (Table 3).

Quantitative detection of $V$. dahliae in infected smoke tree tissues. The primer pair VdF1/VdR1 was used to specifically amplify the region of 5.8S rDNA-ITS in $V$. dahliae; the primers did not amplify fragment from $V$. albo-atrum, $V$. nigrescens, $V$. tricorpus, Trichoderma harzianum, Penicillium spp., Cylindrosporium sp., Fusarium spp., Oidiodendron sp., Gliomastix sp., Cryphonectria parasitica, Xylaria hypoxylon, Rhizoctonia solani, Alternaria alternata, and Pythium ultimum (data not shown). Based on the sequence of the amplicon of $\mathrm{VdF} 1 / \mathrm{VdR} 1$, the nested primers VdF2VdR2 were designed to the ITS region (Table 2). The primers were tested by conventional nested PCR against genomic DNA from fungal isolates (Table 1); the 100-bp product was specifically amplified only from isolates of $V$. dahliae (Table 1 ). The specificity of the primers also was tested by SYBR Green-based qPCR. Other fungal and plant DNA showed no amplification products using qPCR; however, $V$. dahliae isolates showed positive amplification (Fig. 2). These results indicate that the selected primers are highly specific for $V$. dahliae. In order to enhance the detection efficiency of qPCR, the qPCR applying a nested approach was constructed in this study, designated QNRT-PCR. The seven 10-fold dilutions of $V$. dahliae DNA can be clearly detected in QNRT-PCR, whereas only the first five 10-fold dilutions could be detected by conventional qPCR.

We used this QNRT-PCR method to quantify the pathogen DNA in infected smoke tree tissues. Based on the observable wilt symptoms, total DNA was extracted from naturally infected smoke tree tissues, including roots, stems, branches, and leaves. Then, QNRTPCR was conducted as described in Materials and Methods. Positive SYBR Green QNRT-PCR signals were found in all plant tissues and these results were confirmed by isolating $V$. dahliae from these sample tissues. QNRT-PCR analyses showed that the amount of $V$. dahliae DNA was approximately $500 \mathrm{pg} / \mathrm{g}$ in root, $400 \mathrm{pg} / \mathrm{g}$ in stem or branch, and $200 \mathrm{pg} / \mathrm{g}$ in leaves (Fig. 3). Verticillium wilt

Table 3. Incidence and disease rating of Verticillium wilt of smoke tree in Fragrant Hills during 2008 to 2011

\begin{tabular}{|c|c|c|c|c|c|}
\hline \multirow[b]{2}{*}{ Year } & \multicolumn{2}{|c|}{ Incidence $(\%)^{x}$} & \multicolumn{2}{|c|}{ Disease ratingy } & \multirow[b]{2}{*}{ Mortality $^{\mathrm{z}}$} \\
\hline & Mean & Range & Mean & Range & \\
\hline 2008 & $72.5 \mathrm{a}$ & $62.0-86.0$ & $1.3 \mathrm{a}$ & $0.7-2.6$ & 2 \\
\hline 2009 & $78.5 \mathrm{~b}$ & $70.0-90.0$ & $1.6 \mathrm{a}$ & $0.9-3.0$ & 5 \\
\hline 2010 & $85.0 \mathrm{~b}$ & $76.0-92.0$ & $2.1 \mathrm{~b}$ & $1.4-3.6$ & 7 \\
\hline 2011 & $90.5 \mathrm{c}$ & $84.0-98.0$ & $2.8 \mathrm{~b}$ & $2.2-3.9$ & 15 \\
\hline
\end{tabular}

${ }^{\mathrm{x}}$ Incidence was calculated from the number of infected plants in all 50 smoke trees in each plot. Mean incidence scores were calculated from the incidence score of four plots.

${ }^{\mathrm{y}}$ Disease rating was given on a 0 -to- 4 scale $(0=$ no wilting to $4=$ more than $85 \%$ of the leaves wilted or dropped or the whole plant died).

${ }^{\mathrm{z}}$ Mortality showed the number of dead smoke trees that resulted from Verticillium wilt every year. Values with different letters are significantly different according to least significant difference test $(P<0.05)$.

\section{$\begin{array}{lllllllllllllllllllllllll}M & 1 & 2 & 3 & 4 & 5 & 6 & 7 & 8 & 9 & 10 & 11 & 12 & 13 & 14 & 15 & 16 & 17 & 18 & 19 & 20 & 21 & 22 & 23 & 24\end{array}$}

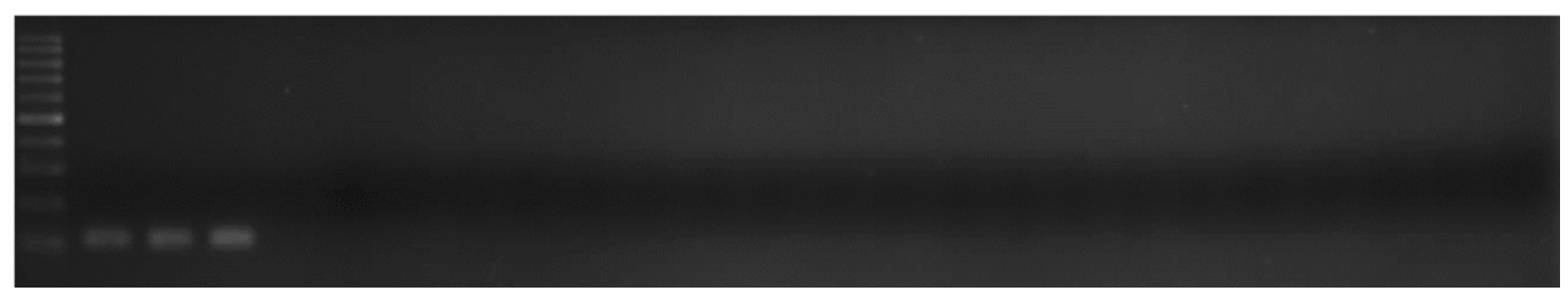

Fig. 2. Specificity of the primer pairs. Agarose gel electrophoresis of nested quantitative polymerase chain reaction products amplified using the two sets of primers VdF1/VdR1 and VdF2/VdR2. Lane M, 100-bp DNA Ladder; lanes 1-3, Verticillium dahliae strains; lanes 4-5, V. albo-atrum from potato; lanes 6-7, V. nigrescens; lane 8, V. tricorpus; lanes 9-19 fungal isolates isolated from smoke tree field soil; lane 9, Trichoderma harzianum; lanes 10-11, Penicillium spp.; lanes 12-13, Cylindrosporium sp.; lanes 14-15, Fusarium spp..; lanes 16-17, Oidiodendron sp.; lanes 18-19, Gliomastix sp.; lane 20, Cryphonectria parasitica; lane 21, Xylaria hypoxylon; lane 22, Rhizoctonia solani; lane 23, Pythium ultimum; and lane 24, Cotinus coggygria. 
displays two different symptoms on leaves (Fig. 1C and D) but QNRT-PCR analyses showed that there was no significant difference in the amount of $V$. dahliae DNA between these two types of symptoms (Fig. 3, leaf I and leaf II).

To analyze the relationship between the amount of $V$. dahliae DNA and different wilt disease ratings, we quantified the pathogen DNA in plants with different disease ratings on a 0 -to-4 scale Branches from three infected smoke trees, which were classified in the same disease rating, were collected. Samples from each disease rating were collected in the same way. DNA was extracted and analyzed by QNRT-PCR assays. The amount of $V$. dahliae DNA in plants was proportional to the wilt disease severity (Fig. 4). The amount of pathogen DNA showed significant differences among plants in different disease ratings.

Correlation between $V$. dahliae inoculum density in soil and different wilt disease ratings in smoke tree fields. In order to determine whether QNRT-PCR could be used to detect and quan-

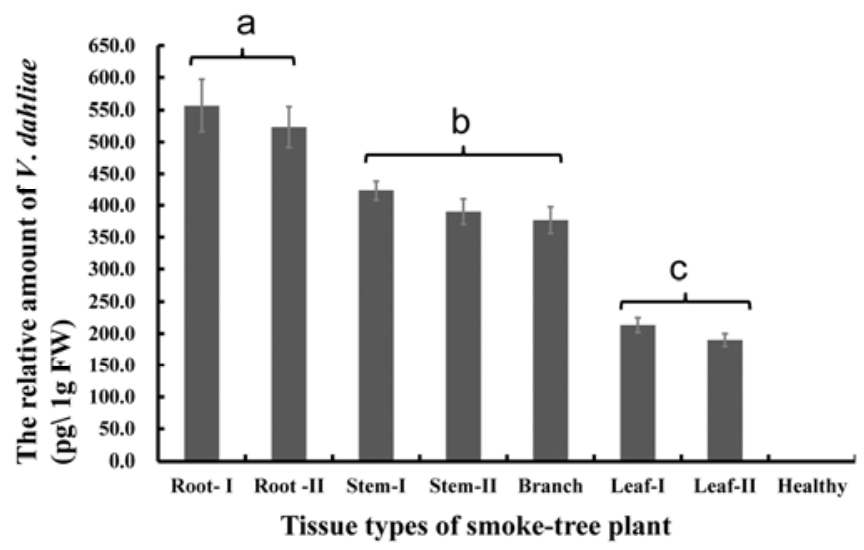

Fig. 3. Quantification of Verticillium dahliae DNA in roots, stems, and leaves of naturally infected smoke tree. DNA amount (picograms per gram of fresh weight $[\mathrm{pg} / \mathrm{g} \mathrm{FW]}$ ) of $V$. dahliae in roots, stems, branches, and leaves from naturally infected smoke trees sampled in September 2011. Root-I and -II denotes the main root and the lateral root, respectively; Stem-I and -II denotes the base and the top of the stem, respectively; Leaf-I denotes a leaf displaying yellow wilt (see Figure 1C); Leaf-II denotes a leaf died in green. Healthy means nonsymptomatic and the root was tested. Vertical bars indicate standard errors; $a, b$, and $c$ indicate statistically significant difference $(P<0.05)$ between the means, respectively.

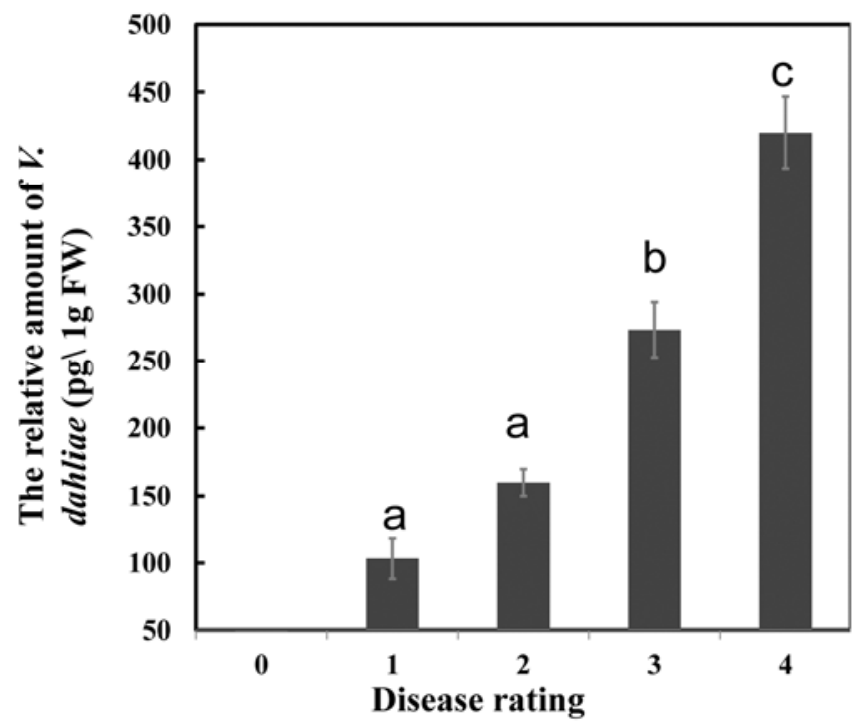

Fig. 4. Quantification of Verticillium dahliae DNA in plants displaying different disease ratings. Amount of DNA (picograms per gram of fresh weight [pg/g FW]) of $V$. dahliae in stems of smoke trees displaying different disease ratings. Numerals indicate different disease ratings of smoke trees. Vertical bars indicate standard errors. Values with different letters for the plot differed significantly at $P<0.05$. tify $V$. dahliae DNA in soil, sterile soil samples inoculated with $V$. dahliae microsclerotia were analyzed by the QNRT-PCR method. Detection was successful starting from 1 microsclerotium/g of soil (Ct value of 33). A linear relationship was established between the $\log$ counts of detected $V$. dahliae microsclerotia and the $\mathrm{Ct}$ value of the PCR assay, which gave an excellent correlation $\left(R^{2}=0.99\right.$; Fig. $5)$. The accuracy of microsclerotia amount determined by QNRTPCR assay was further evaluated by using conventional plating methods. We selected another four smoke tree plots in different disease ratings. DNA was extracted from each soil sample and $V$. dahliae DNA was measured using the QNRT-PCR assay. The highest $\mathrm{Ct}$ value came from the soil sample with the lowest disease rating (Fig. 6). By contrast, the lowest $\mathrm{Ct}$ value came from the soil sample with the highest disease rating (Fig. 6).

The accuracy of QNRT-PCR quantification of the amount of $V$. dahliae in soil was verified by conventional plating experiments (Table 4). We performed direct plating of naturally infested soil samples to measure the density of $V$. dahliae inocula (Table 3 ). From the data of both assays, we concluded that the inoculum density of $V$. dahliae in soil correlated well with the disease ratings in field trials.

\section{Discussion}

In this study, we developed a SYBR Green-based QNRT-PCR to detect and quantify amounts of $V$. dahliae, the causative agent of Verticillium wilt disease of smoke trees. DNA of the pathogen in infected plants and soil was accurately monitored, and QNRT-PCR provided a specific and robust technique for quantifying smoke tree wilt fungus in planta and in soil. Using the method, V. dahliae inoculum in the naturally infested smoke tree field soils was quantified, and this method can serve as a rapid means to monitor and assess risk of smoke tree wilt in Fragrant Hills Park.

PCR is commonly used as a rapid and convenient method to detect plant pathogens. The sequence of the ITS region of rDNA is the best target for designing primers and detecting phytopathogenic fungi $(13,15,26)$. Numerous PCR primers have been designed to detect Verticillium spp. based on this region $(2,3,5,7,11,18,20,21)$. Since the introduction of RT qPCR technology, several qPCR assays have been reported for the detection and quantification of Verticillium DNA in planta and in soil. The pathogen $V$. dahliae does not have a continuous distribution throughout the infected smoke tree tissues, and the pathogen cannot always be detected in the soil. Therefore, it is necessary to develop a quick and accurate method for quantification of pathogen infection (4). Most of the previous studies focused on agricultural crop hosts. To our

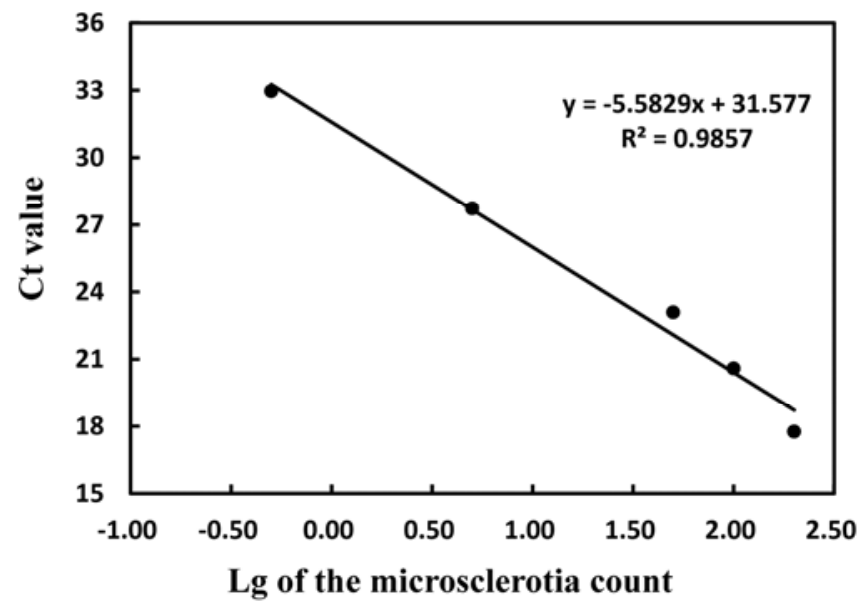

Fig. 5. Linear relationship between mean cycle threshold $(\mathrm{Ct})$ value and the number of Verticillium dahliae microsclerotia in soil. Linear regression of mean Ct value from nested real-time quantitative polymerase chain reaction (PCR) assay from $V$. dahliae versus lg of $V$. dahliae microsclerotia per gram of soil. The $x$ axis indicates lg of microsclerotia of $V$. dahliae per gram of soil. Ct value is cycle threshold from the PCR assay. 
knowledge, the current work is the first report to develop a risk assessment protocol for $V$. dahliae infection in the woody smoke tree host (Cotinus coggygria) in support of disease management strategies to combat the wilt disease. In this study, we developed QNRT-PCR assays and quantified the amount of $V$. dahliae DNA in infected plant tissues. The pathogen distribution in planta was not uniform. The amounts of $V$. dahliae in roots were significantly higher than in stems and leaves.

The incidence and severity of smoke tree wilt increased during the four sequential years of the survey. Verticillium wilt symptoms were often variable (8). There are two types of symptoms in leaves, including yellow wilt (Fig. 1C) and green dry necrotic symptoms (Fig. 1D). Even though the plants were inoculated with the same $V$. dahliae isolate under the same conditions, the plants expressed these two different symptoms (data not shown). The smoke tree leaf samples that displayed two typically different symptoms (Fig. $1 \mathrm{C}$ and $\mathrm{D}$ ) were selected and the amount of the fungus present was quantified. The QNRT-PCR results suggested, however, that there were no significant differences in the amount of $V$. dahlia between leaves with these symptoms (Fig. 3). As for quantities of $V$. dahliae in diseased smoke tree with different disease ratings, the data showed significant differences among plants exhibiting different disease severity, indicating that a higher disease rating follows increased pathogen growth and sporulation in the xylem. Markakis et al. reported that wilt severity is correlated with the amount of DNA of $V$. dahliae in plant tissues (20), consistent with the data from our study. Here, we demonstrated that QNRT-PCR can robustly and accurately detect and quantify the fungus of smoke tree wilt.

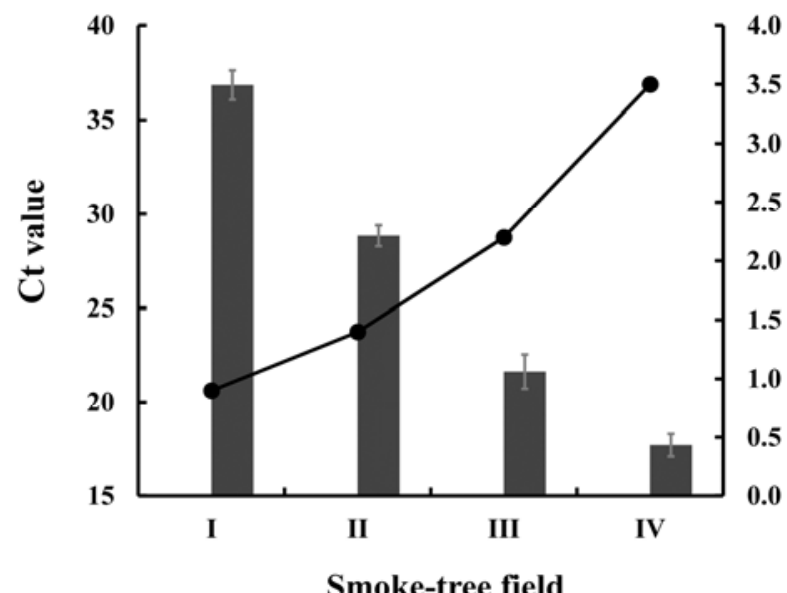

Fig. 6. Quantitative real-time polymerase chain reaction (PCR) cycle threshold (Ct) values and disease ratings of Verticillium wilt in smoke tree fields. Ct values of nested real-time quantitative PCR of Verticillium dahliae soil inocula were correlated with the disease ratings of Verticillium wilt in different smoke tree plots.

Table 4. Quantification of Verticillium dahliae inoculum density in four naturally infested field soils using quantitative nested real-time polymerase chain reaction (QNRT-PCR) assay

\begin{tabular}{lcccc}
\hline & & \multicolumn{2}{c}{ Microsclerotia account } \\
\cline { 4 - 5 } Sample $^{\mathbf{x}}$ & Rating $^{\mathbf{y}}$ & $\mathbf{C t}^{\mathbf{z}}$ & Real-time & Direct $^{\mathbf{w}}$ plating \\
\hline I & 0.9 & 36.8 & 15 & 13 \\
II & 1.4 & 28.3 & 80 & 70 \\
III & 2.2 & 21.6 & 280 & 210 \\
IV & 3.5 & 17.7 & 500 & 400 \\
$\mathrm{H}_{2} \mathrm{O}$ & N/A & 38.5 & N/A & N/A \\
\hline
\end{tabular}

${ }^{\mathrm{w}}$ Numbers represent microsclerotia per gram of soil by calculating from QPCR and plating account methods, respectively; N/A = no amplification.

${ }^{x}$ Soil samples.

${ }^{\mathrm{y}}$ Mean disease rating was calculated from 50 consecutive smoke trees in each plot.

${ }^{\mathrm{z}}$ Mean cycle threshold $(\mathrm{Ct})$ value of three QNRT-PCR replicates.
The QNRT-PCR method was able to detect and quantify $V$. dahliae pathogen DNA from soil DNA collected from smoke tree fields. The sensitivity of this assay allowed accurate detection of 1 microsclerotia/g, which is a similar level of detection relative to other assays for this pathogen. Bilodeau et al. (5) recently reported that TaqMan probe assays had a detection sensitivity of 1 to 2 microsclerotia/g. Lievens et al. (19) reported that the detection limit was 6.7 microsclerotia/g soil for $V$. dahliae. Debode et al. (6) developed a method that detected Verticillium spp. in soils inoculated with $0.5 \mathrm{~V}$. dahliae microsclerotia/g of soil. Compared with these techniques, the nested RT-PCR improved the specificity and sensitivity and provided enough data to quantify the amount of $V$. dahliae in smoke tree fields.

In agreement with other reports $(3,10,20,32)$, a significant relationship was observed between wilt disease ratings and soil inocula densities of $V$. dahliae. In this study, the amount of $V$. dahliae inoculum in soil was determined by the QNRT-PCR assay and conventional plating method. The results showed that the inoculum of $V$. dahliae correlated well with disease ratings in field trials. The $V$. dahliae soil inocula in pure smoke tree fields in Fragrant Hills Park evaluated by QNRT-PCR method were consistent with the survey of the incidence and disease ratings of smoke tree wilt. Therefore, the QNRT-PCR methods in this study can be employed to evaluate the risk of Verticillium wilt disease in soils before smoke tree planting and to contribute to sustainable disease control strategies.

\section{Acknowledgments}

The research was supported by the Fundamental Research Funds for the Central Universities (YX2011-20) and NSFC Project (31000302) to Y. L. Wang, and BJMST Project (Z111106073711001) to C. M. Tian. We thank Dr. A. Li for her critical comments and helpful suggestions on this manuscript.

\section{Literature Cited}

1. Andjic, V., Cole, A. L., and Klena, J. D. 2005. Taxonomic identity of the sterile red fungus inferred using nuclear rDNA ITS 1 sequences. Mycol. Res. 109:200-204.

2. Atallah, Z. K., Bae, J., Jansky, S. H., Rouse, D. I., and Stevenson, W. R. 2007. Multiplex real-time quantitative PCR to detect and quantify Verticillium dahliae colonization in potato lines that differ in response to Verticillium wilt. Phytopathology 97:865-872.

3. Banno, S., Saito, H., Sakai, H., Urushibara, T., Ikeda, K., Kabe, T., Kemmochi, I., and Fujimura, M. 2011. Quantitative nested real-time PCR detection of Verticillium longisporum and V. dahliae in the soil of cabbage fields. J. Gen. Plant Pathol. 77:282-291.

4. Bao, S., Tao, W., and Tian, C. 2011. Histopathological response in the interaction between Cotinus coggygria and Verticillium dahliae. Sci. Silv. Sin. 47:58-65.

5. Bilodeau, G. J., Koike, S. T., Uribe, P., and Martin, F. N. 2012. Development of an assay for rapid detection and quantification of Verticillium dahl iae in soil. Phytopathology 102:331-343.

6. Debode, J., Van Poucke, K., França, S. C., Maes, M., Höfte, M., and Heungens, K. 2011. Detection of multiple Verticillium species in soil using density flotation and real-time polymerase chain reaction. Plant Dis. 95:1571-1580.

7. Duressa, D., Rauscher, G., Koike, S. T., Mou, B., Hayes, R. J., Maruthachalam, K., Subbarao, K. V., and Klosterman, S. J. 2012. A real-time PCR assay for detection and quantification of Verticillium dahliae in spinach seed. Phytopathology 102:443-451.

8. Fradin, E. F., and Thomma, B. P. 2006. Physiology and molecular aspects of Verticillium wilt diseases caused by $V$. dahliae and V. albo-atrum. Mol. Plant Pathol. 7:71-86.

9. Gayoso, C., de Ilárduya, O., Pomar, F., and Merino de Cáceres, F. 2007. Assessment of real-time PCR as a method for determining the presence of Verticillium dahliae in different Solanaceae cultivars. Eur. J. Plant Pathol. 118:199-209.

10. Goud, J.-K., Termorshuizen, A., and Bruggen, A. C. 2011. Verticillium wilt in nursery trees: damage thresholds, spatial and temporal aspects. Eur. J. Plant Pathol. 131:451-465.

11. Goud, J. K., Termorshuizen, A. J., and Gams, W. 2003. Morphology of Verticillium dahliae and V. tricorpus on semi-selective media used for the detection of $V$. dahliae in soil. Mycol. Res. 107:822-830.

12. Hansen, K., Lobuglio, K. F., and Pfister, D. H. 2005. Evolutionary relationships of the cup-fungus genus Peziza and Pezizaceae inferred from multiple nuclear genes: RPB2, beta-tubulin, and LSU rDNA. Mol. Phylogenet. Evol. 36:1-23.

13. Kageyama, K., Komatsu, T., and Suga, H. 2003. Refined PCR protocol for detection of plant pathogens in soil. J. Gen. Plant Pathol. 69:153-160. 
14. Kappe, R., Fauser, C., Okeke, C. N., and Maiwald, M. 1996. Universal fungus-specific primer systems and group-specific hybridization oligonucleotides for 18S rDNA. Mycoses 39:25-30.

15. Klemsdal, S. S., Herrero, M. L., Wanner, L. A., Lund, G., and Hermansen, A. 2008. PCR-based identification of Pythium spp. causing cavity spot in carrots and sensitive detection in soil samples. Plant Pathol. 57:877-886.

16. Klosterman, S. J., Atallah, Z. K., Vallad, G. E., and Subbarao, K. V. 2009. Diversity, pathogenicity, and management of Verticillium species. Annu. Rev. Phytopathol. 47:39-62.

17. Larsen, R. C., Vandemark, G. J., Hughes, T. J., and Grau, C. R. 2007. Development of a real-time polymerase chain reaction assay for quantifying Verticillium albo-atrum DNA in resistant and susceptible alfalfa. Phytopathology 97:1519-1525.

18. Li, K. N., Rouse, D. I., and German, T. L. 1994. PCR primers that allow intergeneric differentiation of ascomycetes and their application to Verticillium spp. Appl. Environ. Microbiol. 60:4324-4331.

19. Lievens, B., Brouwer, M., Vanachter, A. C. R. C., Cammue, B. P. A., and Thomma, B. P. H. J. 2006. Real-time PCR for detection and quantification of fungal and oomycete tomato pathogens in plant and soil samples. Plant Sci. 171:155-165.

20. Markakis, E., Tjamos, S. E., Antoniou, P. P., Paplomatas, E. J., and Tjamos, E. 2009. Symptom development, pathogen isolation and Real-Time QPCR quantification as factors for evaluating the resistance of olive cultivars to Verticillium pathotypes. Eur. J. Plant Pathol. 124:603-611.

21. Mauchline, T. H., Kerry, B. R., and Hirsch, P. R. 2002. Quantification in soil and the rhizosphere of the nematophagous fungus Verticillium chlamydosporium by competitive PCR and comparison with selective plating. Appl. Environ. Microbiol. 68:1846-1853.

22. Nazar, R. N., Hu, X., Schmidt, J., Culham, D., and Robb, J. 1991. Potential use of PCR-amplified ribosomal intergenic sequences in the detection and differentiation of Verticillium wilt pathogens. Physiol. Mol.
Plant Pathol. 39:1-11.

23. Pegg, G., and Brady, B. 2002. Verticillium Wilts. CABI Publishing, Wallingford, Oxfordshire, UK.

24. Perry, J. W., and Evert, R. F. 1982. Structure of microsclerotia of Verticillium dahliae in roots of 'Russett Burbank' potatoes. Can. J. Bot. 62:396401.

25. Platt, H., and Mahuku, G. 2000. Detection methods for Verticillium species in naturally infested and inoculated soils. Am. J. Potato Res. 77:271-274.

26. Qin, L., Fu, Y., Xie, J., Cheng, J., Jiang, D., Li, G., and Huang, J. 2011. A nested-PCR method for rapid detection of Sclerotinia sclerotiorum on petals of oilseed rape (Brassica napus). Plant Pathol. 60:271-277.

27. Salazar, O., Julian, M. C., and Rubio, V. 2000. Primers based on specific rDNA-ITS sequences for PCR detection of Rhizoctonia solani, $R$. solani AG 2 subgroups and ecological types, and binucleate Rhizoctonia. Mycol. Res. 104:281-285.

28. Schena, L., Nigro, F., Ippolito, A., and Gallitelli, D. 2004. Real-time quantitative PCR: a new technology to detect and study phytopathogenic and antagonistic fungi. Eur. J. Plant Pathol. 110:893-908.

29. Schoch, C. L., Seifert, K. A., Huhndorf, S., Robert, V., Spouge, J. L., Levesque, C. A., Chen, W., Fungal Barcoding, C., and Fungal Barcoding Consortium Author, L. 2012. Nuclear ribosomal internal transcribed space (ITS) region as a universal DNA barcode marker for fungi. Proc. Natl. Acad. Sci. USA 109:6241-6246.

30. Stewart, C. N., Jr., and Via, L. E. 1993. A rapid CTAB DNA isolation technique useful for RAPD fingerprinting and other PCR applications. Biotechniques $14: 748-750$

31. Wang, J., Tian, C., and Ge, J. 2008. Research progress of the tree wilt disease caused by Verticillium. For. Pest Dis. 10:30-36. (In Chinese)

32. Xiao, C. L., and Subbarao, K. V. 1998. Relationships between Verticillium dahliae inoculum density and wilt incidence, severity, and growth of cauliflower. Phytopathology 88:1108-1115. 